\title{
POSSIBLE EXTENTION OF REGIONAL STATISTICS - HOUSEHOLDS' WEALTH - METHODS AND PRELIMINARY RESULTS
}

\author{
PETR MUSIL, JANA KRAMULOVA, JAN ZEMAN, VACLAV VRABEC \\ University of Economics in Prague, Faculty of Informatics and Statistics, \\ Department of Economic Statistics, Nam. W. Churchilla 4, Praha 3, Czech Republic \\ email: petr.musil@vse.cz, jana.kramulova@vse.cz,jan.zeman@vse.cz, xvrav00@vse.cz
}

\begin{abstract}
Economic situation of households can be assessed from many perspectives, such as income, consumption or wealth. Indicators describing income, consumption and wealth are so far available for countries only, although step by step more and more attention is paid also to the regional level. Yet official regional statistics is usually limited to several main indicators due to demanding character of indicators' estimation.

We have done academic research and extended the range of available indicators, e.g. regional consumption expenditures in Czech regions. Our subsequent research has been focusing on regional wealth of households whose estimation is more complicated. There are very few possible data sources therefore several models have to be applied. The aim of the paper is to estimate regional wealth of households in 14 Czech NUTS 3 regions. Our results are compared to other indicators published in regional accounts. Also, the analysis of incompatibility of indicators is carried out. Regional differences in wealth may vary from differences in income or expenditure as the nature of indicators is dissimilar. On one hand, wealth expresses status on the particular date resulting from the previous accumulation as well as from households' preferences (e.g. living in own or rented dwelling). On the other hand, income and expenditure describe transactions occurring during the given period regardless previous transactions. The results may lead to slightly different assessment of regional well-being of households.
\end{abstract}

Key words: regions, national accounts, households, wealth

JEL Codes: E21, R13, R20

DOI: 10.15611/amse.2017.20.26

\section{Introduction}

Our focus is in the long term dedicated to regional statistics or more properly to regionalization of national statistics. From regionalization of final expenditures, price levels or input-output tables we moved our attention to economic situation of households (one sector of total economy).

Economic situation of households is a very attractive topic, but is not so easy to measure. It can be assessed from many perspectives, such as income, consumption or wealth. Ondrus (2015) emphasizes that comprehensive analyses of the Czech households' wealth are not frequent due to more reasons - preference of production/expenditure approach, lower quality of wealth data, lack of international comparison and others. Crawford, Innes, and O'Dea (2016, pp. 36) confirm that in Great Britain "[ $t]$ here has traditionally been less micro data available on household wealth than on income or spending". Nowadays, the discussion revolves around 
the confrontation of performance on one hand and wealth on the other hand, because these two aggregates are interconnected.

Indicators describing income, consumption and wealth are so far available for countries only, although step by step more and more attention is paid also to the regional level. We extended the range of available indicators in the recent years; we estimated e.g. regional consumption expenditures in Czech regions (Kramulova and Musil, 2013).

The difference from our previous work stands also in the fact that e.g. final consumption expenditures represent flow indicator (i.e. sum of money spent during the given period), whereas wealth is an example of stock indicator (i.e. shows accumulated value of wealth to the particular date).

It is obvious that national wealth influences macroeconomic dynamics (especially consumption), therefore it is analyzed mainly by analytics from central banks or economic scientists, which focus at the national level. Mostly the analyses relate to assessment of impact of changes in wealth on household consumption and the overall macro-economy (e.g. Cooper and Dynan, 2016). Time series are analyzed, especially with respect to last big economic and financial crisis after the year 2009 (e.g. Rauscher and Elliott, 2016). Another type of analyses refers to distribution of total national household wealth according to age or social group (e.g. Crawford, Innes, and O'Dea, 2016, Rosnick and Baker, 2014). The third type of papers compares national wealth of different countries (e.g. Euro area in Mathä, Porpiglia and Ziegelmeyer, 2017 or in Leitner, 2016). From the literature review it is clear, that this topic is important and there is a rising pressure on availability of greater amount of better and more reliable data all over the world. Especially the connection to financial crisis showed that wealth should be analyzed more often and deeper. As Crawford, Innes, and O'Dea (2016, pp.36) state, "[a] household with enough wealth can maintain its living standards when income falls unexpectedly (for example, due to unemployment), when income falls expectedly (for example, due to retirement) or when needs increase (for example, due to a negative health shock)".

Very important part of the topic is to analyze the homeownership (see e.g. Cooper and Dynan, 2016, Maroto and Aylsworth, 2016, Mathä, Porpiglia and Ziegelmeyer, 2017), because this has a huge impact on total wealth of a household, including intra-generational transfers. There is a substantial difference, if the household is a homeowner, is with mortgage or under the lease.

Usually the total household wealth is further divided into several types, e.g. Office for National Statistics (2013) distinguishes net property wealth, net financial wealth, physical wealth and private pension wealth.

Regional analyses of wealth are much less often. We can highlight e.g. Great Britain (Office for National Statistics, 2013), that analyses wealth in households in the regional structure. The country is divided into following 11 regions: North East, North West, Yorkshire \& The Humber, East Midlands, West Midlands, East of England, London, South East, South West, Wales and Scotland. Similar research was done in Slovakia (Messner and Zavadil, 2014) for 8 Slovak NUTS 3 level regions: Bratislava region, Banská Bystrica region, Košice region, Nitra region, Prešov region, Trenčín region, Trnava region and Žilina region. Region stand as one of the variables also in the model of Rauscher and Elliott (2016), however they split USA just to four regions - Northeast, North Central, South and West. Xu, and Kong (2015) divide Chinese urban regions into eastern (coastal), central, and western regions, however they analyze consumption behavior of households and wealth is just one of the variables in the model.

As in regional statistics in general, we again face the problem with lack of data, as for NUTS 3 level (14 Czech regions) just several main indicators are published by official 
statistics. Moreover, even at the national level some data challenges may be seen (Ondrus, 2015, Cooper and Dynan, 2016, Crawford, Innes, and O'Dea, 2016). Considering regional level, we can face the problem we discussed earlier in the research dedicated to expenditure approach and the area of consumption - regional price levels can and will influence regional wealth as well (Cadil et al., 2014, Kramulová et al., 2016). The aim of the paper is to estimate regional wealth of households in 14 Czech NUTS 3 regions. We performed the analyses for the year 2014 .

Special techniques focused on small area estimation can be found in the literature. These small area statistical models that usually work with two datasets - aggregate and individual (e.g. Iterative Proportional Fitting (IPF) and Penalized maximum entropy model (P-MEDM) in Rose and Nagle, 2017 or demographic housing unit model (HU) in Deng and $\mathrm{Wu}, 2013$ ). However, this is not the case of our research as we work only with data from national accounts, i.e. with aggregates not using any individual or household data from surveys or demographic issues. These national accounts data are further being regionalized. Moreover, we draw our attention on NUTS 3 level regions that are already quite big having in some cases even more than 1 million inhabitants forming a great amount of households.

The paper is organized as follows: Section 2 presents net wealth in the Czech Republic (including closing balance of household sector in the year 2014). Section 3 provides information about regionalization method we applied. This section is further divided and gives description of regionalization of non-financial assets, financial assets and financial liabilities. Section 4 introduces preliminary results of regional distribution of financial net worth of households. Section 5 is devoted to discussion and conclusion.

\section{Net wealth in the Czech Republic}

Although the demand for stock indicators is still increasing the availability is quite limited. Very few countries, even member states of the EU, publish opening and closing balances of national economies in sector breakdown. Usually, just selected indicators are published. However, this breakdown is crucial as it makes possible to analyze income, expenditures and net wealth of households. Total net wealth of national economies can be also compared internationally, however its sector structure may differ because of many reasons such as natural resources owned by government, financial assets or intellectual property products in particular countries.

Fortunately, the Czech Statistical Office publishes balances in sector breakdown annually. Moreover, subsector division is also available in the Czech Republic. Nevertheless, specific breakdown of household sector is applied by the Czech Statistical Office. Household as entrepreneurs consists of households that are recognized as unincorporated business whose assets and liabilities related to business activity cannot be split. The breakdown helps to describe production process within household sector but does not provide any regional data. Actually, the breakdown is not in line with standard ESA 2010 which recognizes subsectors by social groups of households.

About 57\% of households' assets are non-financial whereas $43 \%$ financial. Among nonfinancial assets the most important are dwellings that are mainly used for own final use. Other types of produced non-financial assets are employed within production process only (with a minor exception of valuables). Regarding non-produced assets households own land others are negligible. Among financial assets households are owners of currency and deposits (about $22 \%$ ) and equity, shares etc. (about 12\%). These items prevail in financial assets. Loans (e.g. mortgage, consumer loan) represent liabilities of households, others can be omitted. Net wealth of households is about 9.4 bil. CZK that represents about one third of national economy (see Table 1 below). 
Table 1: Closing balance of household sector, 2014

\begin{tabular}{|c|c|c|c|c|}
\hline Code & Title & $\begin{array}{c}\text { Households } \\
\text { S.14 }\end{array}$ & $\begin{array}{c}\text { Households as } \\
\text { entrepreneurs } \\
\text { S.141 }\end{array}$ & $\begin{array}{c}\text { Households } \\
\text { as consumers } \\
\text { S.142 }\end{array}$ \\
\hline \multicolumn{5}{|c|}{ Assets } \\
\hline AN & Non-financial assets & 6179976 & 1259225 & 4920751 \\
\hline AN.1 & Produced non-financial assets & 4948772 & 1178047 & 3770725 \\
\hline AN.11 & Fixed assets by type of asset & 4517608 & 779942 & 3737666 \\
\hline AN.111 & Dwellings & 4088275 & 350609 & 3737666 \\
\hline AN.112 & Other buildings and structures & 177929 & 177929 & \\
\hline AN.113 & Machinery and equipment & 246225 & 246225 & \\
\hline AN.115 & Cultivated biological resources & 1531 & 1531 & \\
\hline AN.117 & Intellectual property products & 3648 & 3648 & \\
\hline AN.12 & Inventories & 298384 & 298384 & \\
\hline AN.13 & Valuables & 132780 & 99721 & 33059 \\
\hline AN.2 & Non-produced non-financial assets & 1231204 & 81178 & 1150026 \\
\hline AN.21 & Natural resources & 1230955 & 80929 & 1150026 \\
\hline AN.22 & Contracts leases and licenses & 249 & 249 & \\
\hline AF.a & Financial assets & 4684401 & 239990 & 4444411 \\
\hline AF.2 & Currency and deposits & 2420778 & 131195 & 2289583 \\
\hline AF.21 & Currency & 321834 & 27654 & 294180 \\
\hline AF.22 & Transferable deposits & 1402080 & 66512 & 1335568 \\
\hline AF.29 & Other deposits & 696864 & 37029 & 659835 \\
\hline AF.3 & Debt securities & 174944 & & 174944 \\
\hline AF. 5 & $\begin{array}{l}\text { Equity and investment fund } \\
\text { shares/units }\end{array}$ & 1319900 & & 1319900 \\
\hline AF.51 & Equity & 1052889 & & 1052889 \\
\hline AF.52 & Investment fund shares/units & 267011 & & 267011 \\
\hline AF.6 & $\begin{array}{l}\text { Insurance pension and standardized } \\
\text { guarantee schemes }\end{array}$ & 638902 & 6201 & 632701 \\
\hline AF.61 & Non-life insurance technical reserves & 43403 & 6201 & 37202 \\
\hline AF.62 & $\begin{array}{l}\text { Life insurance and annuity } \\
\text { entitlements }\end{array}$ & 278371 & & 278371 \\
\hline AF.63 & Pension entitlements & 317128 & & 317128 \\
\hline AF.7 & $\begin{array}{l}\text { Financial derivatives and employee } \\
\text { stock options }\end{array}$ & 151 & & 151 \\
\hline AF.8 & Other accounts receivable/payable & 129726 & 102594 & 27132 \\
\hline \multicolumn{5}{|c|}{ Liabilities and net worth } \\
\hline AF.z & Financial liabilities & 1438406 & 126393 & 1312013 \\
\hline AF. 3 & Debt securities & 120 & 120 & \\
\hline AF.4 & Loans & 1311308 & 45125 & 1266183 \\
\hline AF.8 & Other accounts receivable/payable & 126978 & 81148 & 45830 \\
\hline B.90 & Net worth & 9425971 & 1372822 & 8053149 \\
\hline BF.90 & Financial net worth & 3245995 & 113597 & 3132398 \\
\hline
\end{tabular}

Source: Czech Statistical Office, author's adaption 


\section{Regionalization method}

We applied top down for regionalization. i.e. total amount for national economy was distributed to regions using appropriate regionalization key. Bottom up method could not be used as there is no regional data available. In spite of our experience from the previous research it was not simple to establish appropriate key for each item of the balance. The attention was drawn to the most important items.

\subsection{Regionalization of non-financial assets}

Undoubtedly, dwellings are the most important assets owned by households. Besides, they form about two third of non-financial assets dwellings serve to satisfy one of the most important human needs. Apart from other assets and liabilities, the unique data source (Census) is available. Characteristics of every dwellings were surveyed within Census in 2011. However, the latest census was carried out in 2011, but it can be assumed that regional structure has not changed significantly. Therefore, so called price quantity approach was applied. Area in each region was multiplied by average price. Nevertheless, the total value did not match the value of dwellings in the balance sheet because of several reasons: missing quality adjustment or different age structure in regions. Detailed analysis is being carried out. Two data sources on prices were taken over: average prices of dwellings published by the Czech Statistical Office and data collected by specialized company (Institut regionálních informací). Very preliminary results were published in Zeman and Vrabec (2016). The highest value of dwelling per capita is observed in Prague (more than 800 thousand CZK) while the lowest is recorded in Ústecký kraj (about 200 thousand). Flats prevail in Prague whereas houses constitute majority of dwellings in other regions.

Fixed assets, apart from the most important item of dwellings, include items whose representation is relatively insignificant but they are relatively well usable for the purposes of regionalization. These are:

- other buildings and structures,

- machinery and equipment,

- cultivated biological resources,

- products of intellectual property.

We also included the item of inventories representing the other part of non-financial assets but its regionalization is performed in the same way.

The main advantage of all these items is the fact that they belong only to the sub-sector S.141 (households acting as entrepreneurs). This can be fairly well used as the Czech Statistical Office publishes data about the number of self-employed people in the form of which households can act as the only one of all the sectors. These data are also available broken down by the main sections of $\mathrm{CZ}^{-N A C E^{1}}$ classification. The structure of selfemployed people is the first key data source for the regionalization of the above-mentioned items. The second key data source is the data available in the balance sheet where items of fixed assets, inventories and valuables are broken down again according to CZ-NACE (mainly in the two- or three-digit breakdowns).

The basic idea is therefore to use the data from this balance sheet with its items being regionalized based on the structure of the self-employed. A minor complication is the fact that the data on the item of valuables are available only in the total amount but information on their representation among sections of CZ-NACE is not available. Regionalization of this item

\footnotetext{
1 Nomenclature générale des Activités économiques dans les Communautés Européennes (statistical classification of economic activities used by the European Union)
} 
will need to be solved separately. To sum up, in this way we regionalize all fixed assets (except for dwellings) and all items of inventories. Dwellings and the group of non-produced non-financial assets is regionalized separately.

Based on the results, the dominance of Capital city of Prague is quite obvious with the exception of the item "cultivated biological resources" where the regions with a higher proportion of land dominate. Ranking of the individual regions is relatively consistent across all regionalized items. Karlovarsky region as the smallest region in the Czech Republic with the lowest number of inhabitants is ranked the last. The share structure of the item "other buildings and structures" is strongly correlated with the presence of big towns (Prague as both the capital city and the region located in the center of Stredocesky region; Brno in Jihomoravsky region and Ostrava in Moravskoslezsky region) for which a large part of the built-up area is typical. There is also high proportion of the item "machinery and equipment" as the production, especially industrial, is concentrated in these towns. The aggregated structure of all the regionalized items is shown in Figure 1.

Figure 1: Regionalization of selected fixed assets and inventories (in CZK millions).

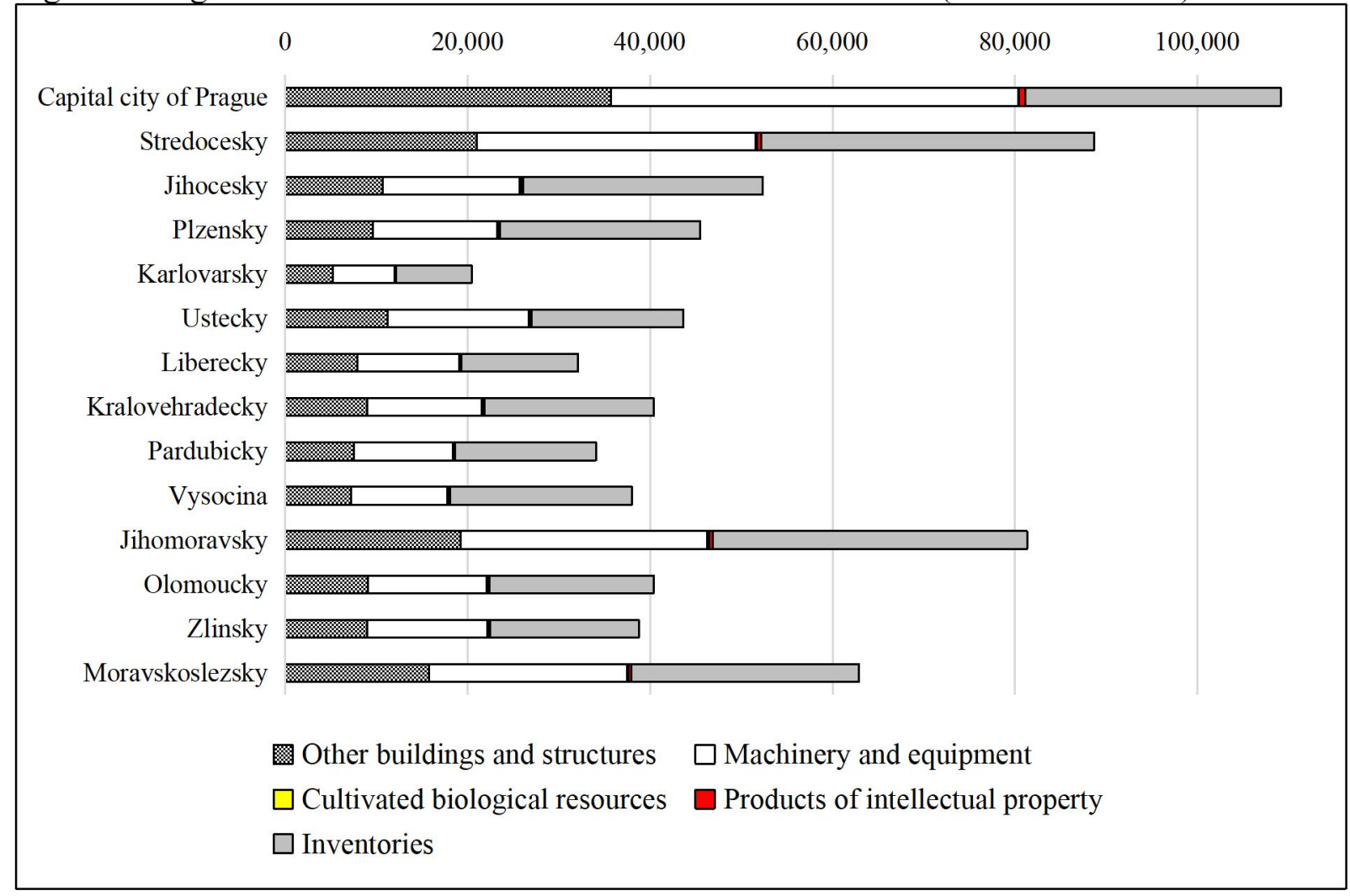

Source: the author's work

\subsection{Regionalization of financial assets}

The second part of the group of fixed assets is represented by the financial assets of households. They serve mainly as a store of value and bring benefits arising from their possession to its owner (European Commission, 2010). Regarding regionalization of this group of assets, this issue has not been practically solved in the literature so far and therefore becomes quite complicated. For this reason, we were forced to accept a simplistic approach to its regionalization. We chose such a regionalization key that would ensure particularly substantive affiliation on this issue and provide at least partially satisfying results. In this case, we chose the indicator of net households' Disposable income (hereinafter NHDI) belonging in the area of financial incomes by definition. The NHDI includes the following items: 
- wages and salaries of employees,

- income of entrepreneurs in the sector of households,

- net income from assets,

- net social income.

Stratification of the NHDI is shown at Figure 2. It is clear the highest share belongs to the Capital city of Prague (15.5\%) followed by Stredocesky region (13.3\%). On the contrary, the lowest proportions are achieved by the smallest regions located in the north and northwest of the Czech Republic (Liberecky region with a share of 3.9\%; Karlovarsky region with a share of $2.6 \%$ ). The position of Ustecky region is quite specific as it is an average-sized region (seventh largest out of 14) but compared to the similarly sized regions, it is occupied by a relatively high share of population. Thus, although it has the fifth highest NHDI, if we evaluated the regions by the NHDI per capita, it would be ranked the last (14 percentage points below the national average). Based on the structure of NHDI, we then calculated individual items of financial assets for each of the regions. Results are also included in Figure 2.

The value of the total households' financial assets amounted to nearly 4.7 trillion CZK in 2014 of which the vast majority (over 95\%) belongs to the sector of households acting as consumers. More than a half of the total financial assets $(51.7 \%)$ is formed by the currency and deposits. The second highest is the item of investment fund participation and shares $(28.2 \%)$.

When comparing the individual regions, the amount of financial assets is again in favour of the most populous regions with the biggest cities located in or its surroundings. Namely, Capital city of Prague, Stredocesky region, Jihomoravsky region and Moravskoslezsky region. These four regions cover approximately half of the total financial assets.

Figure 2: Net households' disposable income and total households' financial assets in Czech NUTS 3 regions in 2014 (in CZK billions).

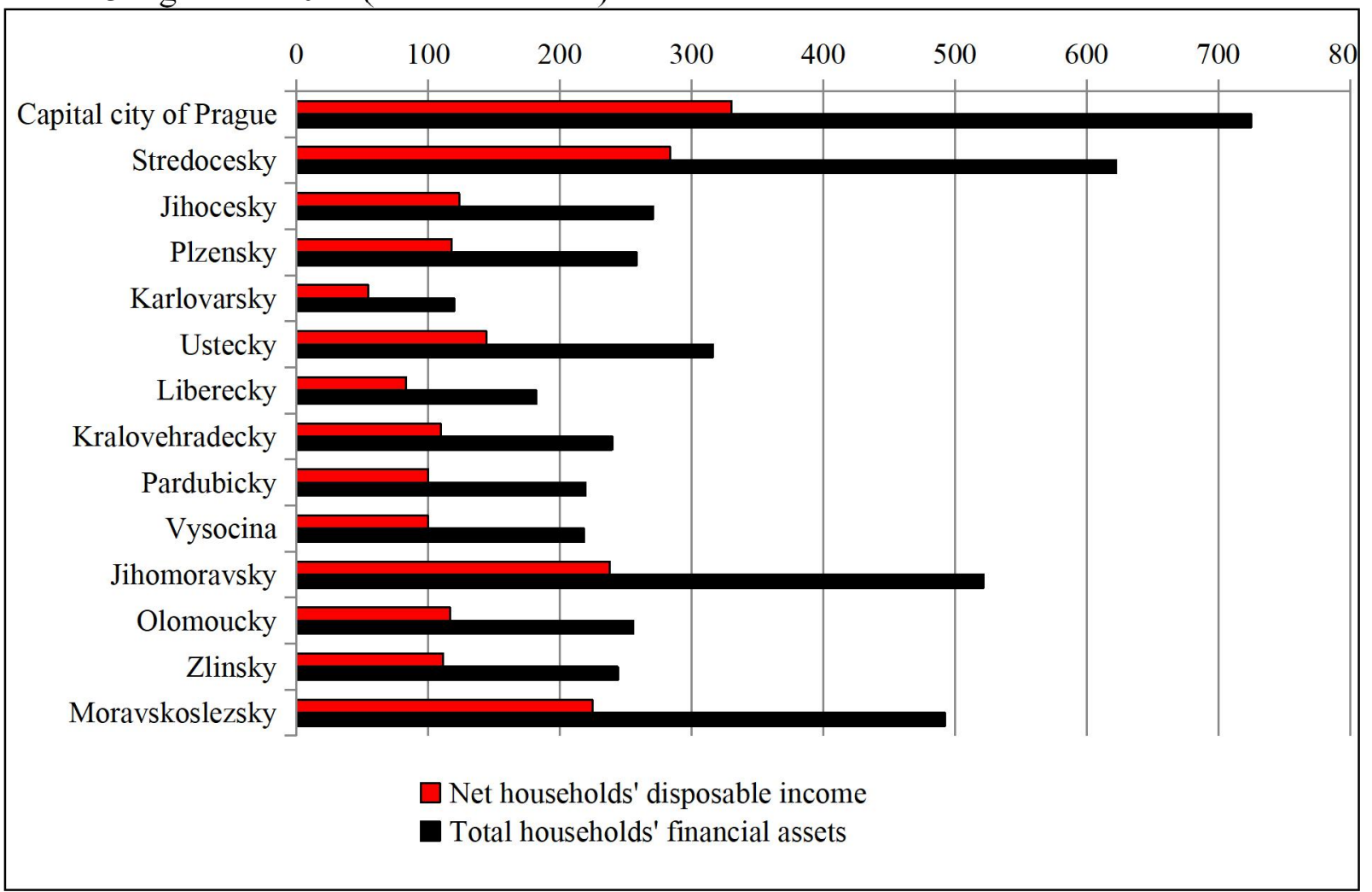

Source: the author's work 


\subsection{Regionalization of financial liabilities}

Financial liabilities form the side of passives in the balance sheet. Total households' liabilities amounted to 1.44 billion CZK in 2014, of which only $9 \%$ belong to the sub-sector S.141 (households acting as entrepreneurs) and the rest to S.142 (households acting like consumers). Households' liabilities are to be found in a very limited extent in the form of debt securities (120 million CZK). On the contrary, the largest amount of liabilities belongs to the group of loans with the vast majority of long-term loans paid off over time frame exceeding one year. The last item contributing to the total liabilities is "other receivables/commitments". This category includes financial liabilities created as a counterpart to the financial or nonfinancial transaction, where there is a time mismatch between the transaction and the corresponding payment.

Similarly to the financial assets, there is no clear regionalization key under which the precise shares of the regions in the total liabilities, that have incurred, can be determined. The question of regionalization of this item is being dealt with at the time of writing this contribution. As a provisional solution, we decided to use the information on mortgage loans provided to households in 2014, published by the Ministry of Regional Development. Based on the structure of mortgage loans, we then delineated these three above-mentioned items. In 2014 approximately 85 thousands mortgage loans were granted and nearly a quarter of them in the Capital city of Prague. The amount of the contractual principal covered almost one-third of the total. This is not surprising given that many inhabitants set up their dwellings in the Capital city of Prague every year. In most cases they cannot be obtained without a mortgage loan. With great distance regions Jihomoravsky (principal of 15.8 million CZK representing $11.2 \%$ ) and Moravskoslezsky (principal of 11.4 million CZK representing $8.1 \%$ ) are to be found. The lowest principal amount was agreed in Karlovarsky region $(2.7$ million CZK representing only less than $2 \%$ ). Results are provided by Table 2 .

Table 2: Regionalization of financial liabilities according to the structure of mortgage loans in Czech NUTS 3 regions (in CZK millions)

\begin{tabular}{crrr}
\hline NUTS 3 region & Debt securities & \multicolumn{1}{c}{ Loans } & $\begin{array}{c}\text { Other claims and } \\
\text { liabilities }\end{array}$ \\
\hline Capital city of Prague & 39.30 & 429491.67 & 41589.00 \\
Stredocesky & 6.68 & 73024.06 & 7071.14 \\
Jihocesky & 6.38 & 69762.53 & 6755.32 \\
Plzensky & 6.33 & 69143.07 & 6695.34 \\
Karlovarsky & 2.35 & 25626.03 & 2481.45 \\
Ustecky & 5.14 & 56212.09 & 5443.19 \\
Liberecky & 4.23 & 46176.06 & 4471.37 \\
Kralovehradecky & 6.45 & 70481.57 & 6824.95 \\
Pardubicky & 5.87 & 64117.84 & 6208.73 \\
Vysocina & 3.53 & 38589.65 & 3736.76 \\
Jihomoravsky & 13.49 & 147455.40 & 14278.56 \\
Olomoucky & 5.94 & 64909.89 & 6285.42 \\
Zlinsky & 4.58 & 50079.58 & 4849.36 \\
Moravskoslezsky & 9.72 & 106238.55 & 10287.41 \\
\hline
\end{tabular}

Source: the author's work 


\section{Net worth of households: preliminary results}

At the moment, as the regionalization of the item of valuables within the non-financial assets has not been completed yet, we can present only the preliminary results of the financial net worth indicator emerging as a balancing item between financial assets and financial liabilities (and unlike the net worth it does not take into account non-financial assets). The results are summarized in Table 3.

According to the preliminary results the best performing region is Stredocesky where almost $17 \%$ of all financial net worth are gathered. At a slight distance, there are other large regions such as Jihomoravsky and Moravskoslezsky with a share over $11 \%$. Due to the very high price level in the Capital city of Prague (Kramulová et al., 2016) reflecting the higher need for funding of households' needs (e.g. dwellings) from foreign resources, this region is ranked fifth with a share of less than $8 \%$, although it is the richest region with the largest proportion of financial assets. Performance of other regions is already relatively balanced and consistent with the ongoing regionalization results. The last place is again occupied by Karlovarsky region despite the lowest level of financial liabilities; however, its level of financial assets is also the lowest. It is also given by its size and a low share of population to some extent. If we compared the financial net worth per capita, Stredocesky region would be again ranked first (414 thousands CZK). Vysocina region (345 thousands CZK) and Zlinsky region (323 thousands $\mathrm{CZK}$ ) would also be at the forefront. On the contrary, the worst performance arises in the case of Capital city of Prague with only 203 thousands CZK per capita.

Table 3: Financial Net Worth and its Components by NUTS 3 Regions (in CZK millions)

\begin{tabular}{cccc}
\hline NUTS 3 region & Financial assets & $\begin{array}{c}\text { Financial } \\
\text { liabilities }\end{array}$ & Financial net worth \\
\hline Capital city of Prague & 724735 & 471120 & 253615 \\
Stredocesky & 622069 & 80102 & 541967 \\
Jihocesky & 270540 & 76524 & 194016 \\
Plzensky & 258204 & 75845 & 182359 \\
Karlovarsky & 119596 & 28110 & 91486 \\
Ustecky & 315986 & 61660 & 254326 \\
Liberecky & 182085 & 50652 & 131433 \\
Kralovehradecky & 239680 & 77313 & 162367 \\
Pardubicky & 219415 & 70332 & 149083 \\
Vysocina & 218481 & 42330 & 176151 \\
Jihomoravsky & 521802 & 161747 & 360055 \\
Olomoucky & 255576 & 71201 & 184375 \\
Zlinsky & 243922 & 54934 & 188988 \\
Moravskoslezsky & 492311 & 116536 & 375775 \\
Czech Republic & 4684402 & 1438406 & 3245996 \\
\hline
\end{tabular}

Source: the author's work 


\section{Conclusion}

Regional statistics offers a set of selected indicators only. Regional national accounts compiled by the Czech Statistical Office provide data on economic performance, investments and incomes of households. We have estimated several indicators that extent official regional statistics such as regional consumption expenditures and regional price levels. It enables a comparison of standard of living among regions. However, more advanced analysis of richness of households could not be performed.

Authors benefit from the previous research focused on regionalization of economic indicators. Various methods were used to allocate assets and liabilities of households to regions. Price quantity approach was applied to dwellings for which selected indicators were surveyed within Census 2011. Nevertheless, several questions arose during our research, such as possible quality adjustments or different data sources on prices. Household sector also consists of unincorporated entrepreneurs who own assets and liabilities used within production process. Different capital intensity by industry was taken into account. Financial assets and liabilities were regionalized using incomes of household, provided mortgages etc. Apart from other countries we cannot use Household Finance and Consumption Survey (HFCS) as it is not carried out in the Czech Republic.

Preliminary results on financial net wealth are provided in the paper. The highest wealth absolutely as well as per capita is recorded in Stredocesky region that constitutes surrounding of the capital city. In the contrary the lowest financial net wealth per capita is observed in the Capital city of Prague. At the first sight it is not in line with other indicators such as economic performance or income. The price level is significantly higher in Prague what may lead to above-average mortgages. This will be subject to the future research and analysis when nonfinancial assets are estimated.

\section{Acknowledgements}

The paper has been prepared under the support of the University of Economics, Prague Internal Grant Agency; project No. IGA 52/2016 "Indicators of Households' Standard of Living with Respect to the Regionalization and Social Groups" and by Institutional Support for Long Period and Conceptual Development of Research and Science at Faculty of Informatics and Statistics, University of Economics, Prague.

\section{References}

[1] Cadil, J., Mazouch, P., Musil, P., Kramulova, J. 2014. True Regional Purchasing Power: Evidence from the Czech Republic. Post-Communist Economies, vol. 26, iss. 2, pp. 241256. DOI: $10.1080 / 14631377.2014 .904109$

[2] Cooper, D., Dynan, K. 2016. Wealth Effects and Macroeconomic Dynamics. Journal of Economic Surveys, vol. 30, iss. 1, pp. 34-55. DOI: 10.1111/joes.12090

[3] Crawford, R., Innes, D., O'Dea, C. 2016. Household Wealth in Great Britain: Distribution, Composition and Changes 2006-12. Fiscal Studies, vol. 37, iss. 1, pp. 35-54.

[4] Deng, Ch., Wu, Ch. 2013. Improving Small-Area Population Estimation: An Integrated Geographic and Demographic Approach. Annals of the Association of American Geographers, vol. 103, iss. 5, pp. 1123-1141. DOI: 10.1080/00045608.2013.770364

[5] European Commission. 2010. Př́loha A návrhu Nařízení Evropského parlamentu a Rady o evropském systému národních a regionálních účtů v Evropské unii, [cit. 18-04-2017] http://ec.europa.eu/transparency/regdoc/rep/1/2010/CS/1-2010-774-CS-F1-7-ANNEX26.Pdf. 
[6] Kramulova, J., Musil, P. 2013. Experimentalni odhad slozek vydajove metody regionalniho HDP $\mathrm{v}$ CR. (Experimental Estimate of Components of Expenditure Approach to Regional GDP in the Czech Republic. With English summary.). Politicka Ekonomie, vol. 61, iss. 6, pp. 814-833.

[7] Kramulová, J., Musil, P., Zeman, J., Michlová, R. 2016. Regional Price Levels in the Czech Republic - Past and Current Perspectives. Statistika: Statistics and Economy Journal, vol. 96, iss. 3, pp. 22-34.

[8] Leitner, S. 2016. Drivers of Wealth Inequality in Euro Area Countries: The Effect of Inheritance and Gifts on Household Gross and Net Wealth Distribution Analysed by Applying the Shapley Value Approach to Decomposition. European Journal of Economics and Economic Policies: Intervention, vol. 13, iss. 1, pp. 114-136.

[9] Maroto, M., Aylsworth, L. 2016. Catching Up or Falling Behind? Continuing Wealth Disparities for Immigrants to Canada by Region of Origin and Cohort. Canadian Review of Sociology, vol. 53, iss. 4, pp. 374-408. DOI: 10.1111/cars.12124.

[10] Mathä, T.Y., Porpiglia, A., Ziegelmeyer, M. 2017. Household wealth in the euro area: The importance of intergenerational transfers, homeownership and house price dynamics. Journal of Housing Economics, vol. 35, pp. 1-12. DOI: 10.1016/j.jhe.2016.12.001

[11] Messner, T., Zavadil, T. 2014. Regional Differences in Household Wealth Across Slovakia: Results from the first wave of the Household Finance and Consumption Survey. Occasional Paper 1/2014. Bratislava: Národná banka Slovenska. [cit. 18-04-2017] http://www.nbs.sk/ img/Documents/PUBLIK/OP 12014_Zavadil_Regional_Differences_Household_Wealth.pdf

[12] Office for National Statistics 2013. Total Household Wealth by Region and Age Group. [cit. 18-04-2017] http://www.ons.gov.uk/ons/dcp171776_313608.pdf

[13] Ondrus, V. 2015. Accounting for Wealth in the Czech Republic. Statistika: Statistics and Economy Journal, vol. 95, iss. 1, pp. 4-18.

[14] Rauscher, E., Elliott, W. 2016. Wealth as Security: Growth Curve Analyses of Household Income and Net Worth during a Recession. Journal of Family and Economic Issues, vol. 37, iss. 1, pp. 29-41. DOI: 10.1007/s10834-015-9442-7

[15] Rose, A.N., Nagle, N.N. 2017. Validation of spatiodemographic estimates produced through data fusion of small area census records and household microdata. Computers, Environment \& Urban Systems, vol. 63, pp. 38-49. 12p. DOI: 10.1016/j.compenvurbsys.2016.07.006

[16] Rosnick, D., Baker, D. 2014. The Wealth of Households: An Analysis of the 2013 Survey of Consumer Finances. Washington D.C.: Center for Economic and Policy Research. [cit. 18-04-2017] http://www.cepr.net/documents/wealth-scf-2014-10.pdf

[17] Xu, J., Kong, D. 2015. Understanding the Household Consumption Behavior in Urban China. Singapore Economic Review, vol. 60, iss. 5, pp. 1-21. DOI: $10.1142 /$ S0217590815500629

[18] Zeman, J., Vrabec, V. 2016. Regionální aktivita domácností. In: Výpočtová štatistika. Bratislava: Slovenská štatistická a demografická spoločnost', p. 19. ISBN 978-80-8894673-1. 
20th International Scientific Conference AMSE

Applications of Mathematics and Statistics in Economics 2017

Szklarska Poręba, Poland

30 August 2017 - 3 September 2017 